\title{
Louis Adamic, 1898-1951: A Retrospective View and Assessment Thirty Years Later
}

\section{Rudolph J. Vecoli}

Immigration History Research Center, University of Minnesota

An international symposium in St. Paul, Minnesota, on the life, work, and legacy of Louis Adamic was held on May 29-30. Smaller meetings were held subsequently in Chicago, Cleveland, Pittsburgh and New York City. The formal occasion for these conferences was the thirtieth anniversary of Adamic's death. But the underlying reason was that Louis Adamic's work has repeatedly engaged our attention and interest in recent years.

During the 1930s and 40s, Adamic was a well-known writer and speaker. His books adorned the bookshelves of every well-read home. His ideas were part of the intellectual furnishings of every well-stocked mind. Then he fell into disfavor and neglect (in part because of the McCarthyism of the early fifties) and was dismissed as a lightweight popularizer, if not a "Red" propagandist. Having rediscovered Adamic, we realize that such characterizations are both unfair and untrue. We once more appreciate that Adamic addressed himself in a serious way to the primary issues of his day and that he did so with extraordinary perspicacity. Not only that, we also have found that he speaks to some of our major concerns today. Adamic, for example, grappled with the dilemma of American pluralism, of achieving unity within diversity and of curing ethnic hatreds and conflicts. He not only explored the social-psychological-political consequences of pluralism, he also prescribed programmatic remedies to heal the fractured social order. Adamic had a vision of America which we find intriguing, if not always convincing. For these and other reasons, the rediscovery of Adamic is symptomatic of our contemporary quest for answers to old questions: what is America? what ought America to be? how do we get from here to there?

The International Symposium on Louis Adamic held in St. Paul was one of two symposia jointly planned by the University of Minnesota and the Edvard Kardelj University in Slovenia, Yugoslavia. The second of them will be held in Ljubljana, Slovenia's capital, September 16-18. The St. Paul conference was funded by the National Endowment for the Humanities with additional financial 
assistance from the Slovene National Benefit Society and the Progressive Slovene Women of America. Seven Yugoslav scholars participated in the St. Paul conference; other participants came from a variety of institutions in the United States and Canada. In this brief report, not all of the twenty-two papers read will be summarized or even mentioned. Rather those presentations will be emphasized which focused on central aspects of Adamic's thought and activity.

In the opening session, Henry A. Christian of Rutgers University-Newark, who is engaged in writing a biography of Adamic, evoked the quality of the man, of his character and mind, with well-selected quotes from manuscript and printed sources and brief footage from a home movie of Adamic. The various sessions that followed were organized around particular facets of Adamic's life, such as his literary career, his involvement in the movement for cultural democracy, his advocacy of Tito's Partisan movement.

The consensus was that Adamic as a writer was certainly not in the first rank as a novelist or literary critic. In her comment upon his two novels, Grandsons (1935) and Cradle of Life (1936), Rose Mary Prosen of Cuyahoga Community College (Cleveland) described them as melodramatic, didactic, and propagandistic, concluding that Adamic "perhaps exceeded his artistic limitations in these novels." In a perceptive analysis of the relationship between Adamic and Frank Mlakar, an aspiring Slovene American writer, Danica Dolenc of the Edvard Kardelj Univeristy found that the dominant personality of Adamic served to thwart the larger talents of Mlakar. He, the Father (1950), Mlakar's only novel, Dolenc judged superior to any fiction that Adamic ever wrote. Jerneja Petric of the Slovenska Izeljenska Matica in Ljubljana described Adamic as neither a deep literary scholar nor an astute critic, declaring that "he judged works of art solely from the ideological viewpoint."

If Adamic was found lacking from a literary point of view, commentators agreed that he was an extraordinarily perceptive reporter and commentator upon current affairs. In an analysis of Adamic's views on the American labor movement, Rudolph J. Vecoli of the University of Minnesota emphasized Adamic's acute understanding of the psychology of American workers. In the thirties, Adamic remained immune to the belief in the impending revolution which deluded so many of the American intelligensia. Although labeled a "Red," he was no Marxist; in fact, he was strongly anti-Communist, believing in the efficacy of American pragmatism as the means to solving the country's problems. The $\mathrm{Na}$ tive's Return, Adamic's account of his year in Yugoslavia while on a Guggenheim Fellowship, was the topic of Ivan Cizmic of the Matica Iseljenika Hrvatske in Zagreb. Cizmic assessed the book as a sensitive and accurate portrayal of life in the Yugoslavia of the early thirties as well as an expose of the tyrannical rule of the "King-dictator" Alexander. Cizmic reviewed the response to The Native's Return in both the United States and Yugoslavia, not all of it friendly.

During the 1930s, Adamic became the outstanding spokesman for the "new Americans," the immigrants and their children, and advocate of a new synthesis of America in which Ellis Island would be as important as Plymouth Rock. His 
writings and activities in behalf of this cause provided the substance of several sessions. Richard Weiss of the University of California-Los Angeles traced Adamic's role in the movement for cultural democracy, a movement which aimed at overcoming fragmentation and integrating the "new Americans" into the national culture, rather than at perpetuating a pluralist society. Greater emphasis was placed upon the pluralistic dimension of Adamic's vision of America both by Nicholas V. Montalto of the International Institute of Jersey City in his treatment of the contribution of Adamic to the multicultural education movement of the inter-war years and by William C. Beyer of the University of Minnesota in his account of Adamic's involvement with the Common Council for American Unity and its multi-ethnic journal, Common Ground. Fred Matthews of York University (Ontario) presented a strong case for the pluralistic implications of Adamic's thought. Comparing him with Horace Kallen and Michael Novak, Matthews concluded that Adamic "gave richer and historically more accurate . . . statements of the kinds of consciousness and sense of identity that would characterize a viable pluralistic society ...' In a sympathetic but critical discussion of Adamic's writing of ethnic history, Robert F. Harney of the University of Toronto contended that in his zeal to provide all Americans with a sense of pride and roots, Adamic had succumbed to filio-piety. Such a therapeutic use of the past was the consequence of Adamic's belief in the need for an inclusive American history which would provide everyone with a sense of belonging. For Harney, however, Adamic celebrated pluralism of origin, and "could not conceive of pluralism of destination in America." His ultimate aspiration was for an amalgamation of cultures which would realize unity out of diversity.

The last decade of his life, Adamic became increasingly involved with the fate of Yugoslavia. Two sessions dealt with his efforts to influence American foreign policy and public opinion on this issue during and after World War II. In his presentation, Matjaz Klemencic of Edvard Kardelj University provided an overview of the response of the Slovene Americans to events in their homeland and their conflicts over which political element to support. He also described Adamic's role as the leading advocate of Tito and his Partisans both among the Slovene Americans and with the Roosevelt administration. The latter topic was more fully treated by Lorraine M. Lees of Old Dominion University who thoroughly documented the efforts of Adamic to persuade the American government to utilize American ethnic groups in establishing a democratic order in postwar Europe and to support the resistance movement led by Tito. Lees determined that Adamic failed on both scores, "not because his ideas had not merit, but because they were out of step with American history and with Roosevelt's wartime policies." The Slovene Catholics and their clerical leaders, while not of one mind, gradually became opposed to the Partisan movement which they believed to be Communist controlled. In treating this subject, Bogdan C. Novak of the University of Toledo depicted this growing animosity among the Catholics towards Adamic.

In the postwar years, Adamic continued to champion the cause of Tito's 
Yugoslavia despite the chilling climate created by the Cold War. His unswerving advocacy was to cost him dearly given the anti-Communist mood of the country. Victor A. Tomovich of Brock University (Ontario) detailed the attacks upon Adamic as an alleged "Red" from the 1930s on and their increasing intensity in the late forties. The toll which these accusations had upon Adamic coupled with other disillusionments were described by two speakers who knew him quite well during these years. As head of the Yugoslav delegation to the United Nations, Joza Vilfan had numerous opportunities to discuss the state of affairs in Yuogoslavia with Adamic. He remembered well how to his surprise Adamic had viewed Tito's break with Stalin as decisive and permanent. John Blatnik, Slovene American Congressman from Minnesota, recalled his impressions of Adamic during his last years, how distraught and withdrawn he had become, which caused Blatnik to conclude that Adamic had indeed probably taken his own life on September 4, 1951 .

The St. Paul symposium clearly probed and portrayed a wide range of topics relating to Louis Adamic. Yet it was the sense of the participants that their discussions had by no means exhausted the subject. Adamic was such a manyfaceted, vital person that he was not about to be disposed of in a two-day conference. These presentations obviously did not add up to the full-bodied biography which is much needed. Nor did they provide definitive treatments of their topics. The symposium did not satiate but rather piqued our interest in Louis Adamic, his life, work, and legacy. 